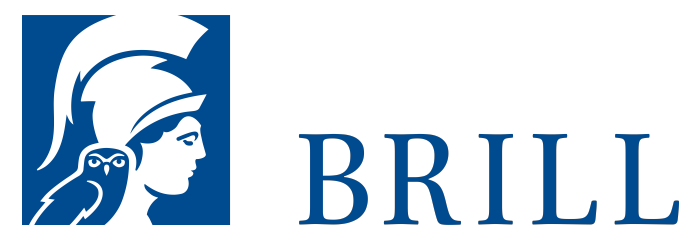

\title{
Theater in der Region
}

Westfalen und Yorkshire 1918-1945

Author: Anselm Heinrich

Theatergeschichte ist allzu oft die Geschichte der Hauptstadttheater. Die meisten Theater sowohl in Deutschland als auch in Großbritannien waren und sind jedoch Regionaltheater. Anselm Heinrich kann zeigen, dass sich die Theater in Bradford, Leeds, Sheffield und York nicht grundsätzlich von denen in Münster, Bielefeld, Dortmund, Bochum und Hagen unterschieden. Die Theater unterlagen jeweils einem ganz ähnlichen wirtschaftlichen Druck: Ein Spielplan musste populär sein, die Zuschauerzahlen wurden genau beobachtet. Weder für britische noch für deutsche Theater gab es Bestandsgarantien - bis 1933, als die Nationalsozialisten begannen, Zuschüsse in bisher nicht gekannten Höhen zu zahlen.

Der Zweite Weltkrieg setzte schließlich ein Denken in Gang, das die regionalen Theater nicht mehr nur als Wirtschaftsunternehmen begriff, sondern in einer stärkeren kulturellen und politischen Funktion sah. Nach 1940 erhielten auch britische Theater Subventionen, und die Erwartungen an einen nicht mehr rein unterhaltenden Spielplan waren denen in Deutschland nicht unähnlich.

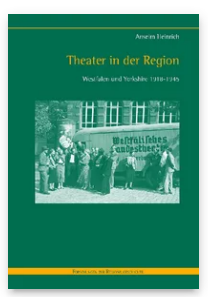

Pages: 340

Seiten, $31 \mathrm{~s} / \mathrm{w}$

Abb.

Language:

German

Subjects: Global

History, History

Publisher: Brill |

Schöningh

Series:

Forschungen zur

Regionalgeschichte,

Volume: 70

E-Book (PDF)

Released online:

og Mar 2020

ISBN: 978-3-

657-77631-3

List price

USD $\$ 63.00$

Hardback

Publication date:

19 Nov 2012

ISBN: 978-3-

5०6-77631-о 
Biographical Note

Anselm Heinrich, Dr., ist Assistant Professor an der University of Glasgow.

For more information see brill.com

\begin{abstract}
Order information: Order online at brill.com
+44330 333 0049 | customerservices@brill.com

Submission information: brill.com/authors
\end{abstract}

Titles published by Brill | Fink, Brill | mentis or Brill| Schöningh:

+49(o)71 5413279216 | brill@brocom.de 